\title{
Differing virulence of Aphanomyces astaci isolates and elevated resistance of noble crayfish Astacus astacus against crayfish plague
}

\author{
J. Makkonen ${ }^{1, *}{ }^{,}$J. Jussila ${ }^{1}$, R. Kortet ${ }^{2}$, A. Vainikka ${ }^{2}$, H. Kokko ${ }^{1}$ \\ ${ }^{1}$ Department of Biology, University of Eastern Finland, 70211 Kuopio, Finland \\ ${ }^{2}$ Department of Biology, University of Eastern Finland, 80101 Joensuu, Finland
}

\begin{abstract}
Crayfish plague epidemics (caused by Aphanomyces astaci) have been causing population collapses among native European crayfish stocks since the late 1800s. Recent indirect and direct evidence has shown that its virulence has been variable, with native European crayfish even acting as carriers. We tested the differences in A. astaci virulence under experimental conditions using both PsI- and As-genotypes with 3 Finnish noble crayfish Astacus astacus populations. We infected crayfish with adjusted quantities of $A$. astaci zoospores and monitored the symptoms and mortality of the crayfish. The PsI-genotype isolate caused rapid and total mortality among the tested populations, while the As-genotype isolates expressed more variable virulence. In some cases, mortality among the As-genotype-infected crayfish did not exceed the mortality level of the control group. All of the tested noble crayfish stocks showed lower mortality towards the As-genotype of $A$. astaci isolated from the River Kemijoki epidemic. We conclude that there are clear differences in virulence between different $A$. astaci genotypes and also differences in virulence within As-genotypes. Furthermore, we observed clear signs of increased resistance in different populations of noble crayfish towards some of the tested strains belonging to the Asgenotype of A. astaci.
\end{abstract}

KEY WORDS: Aphanomyces astaci - Astacus astacus - Disease resistance - Mortality rate · Genotype $\cdot$ Evolution

\section{INTRODUCTION}

Crayfish plague is caused by the oomycete Aphanomyces astaci. It was introduced to Europe in the late 19th century (Cornalia 1860), probably transmitted from North America, and since then it has spread around the Eurasian continent (Alderman 1996). A. astaci has a balanced host-pathogen relationship with North American crayfish species, allowing long-term existence of both the disease and hosts in common environments (Unestam 1969a, 1972, 1975, Souty-Grosset at al. 2006), whereas native European crayfish species, e.g. Astacus astacus, have been very vulnerable to the lethal disease, suffer- ing large-scale population collapses and extinctions (Unestam \& Weiss 1970).

Aphanomyces astaci is a specialized parasite of freshwater crayfish, and neither resting stages nor intermediate hosts have been found in other crustaceans (Söderhäll \& Cerenius 1999). Five major RAPD genotypes of $A$. astaci have been identified (Huang et al. 1994, Diéguez-Uribeondo et al. 1995, Kozubiková et al. 2011), with two of them causing annual crayfish plague epidemics in Finland (Vennerström et al. 1998). Finland is among the last refuges of the Asgenotype, which has been identified as the genotype present in the first invasion of A. astaci to Europe (Makkonen et al. 2012). In most parts of Europe, it has 
presumably been substituted by other genotypes (PsI, PsII, Pc, Or; Royo et al. 2004), after the introductions of alien North American crayfish (Kozubiková et al. 2011), which are known carriers of crayfish plague.

Recently, new highly sensitive PCR applications for the detection of Aphanomyces astaci in carrier crayfish (Oidtmann et al. 2006, Hochwimmer et al. 2009, Vrålstad et al. 2009) have been developed. Along with these new detection methods, several reports of European crayfish species with a latent infection of A. astaci, or acting as carriers of crayfish plague, have been published (Jussila et al. 2011a, ViljamaaDirks et al. 2011, Kokko et al. 2012, Pârvulescu et al. 2012, Svoboda et al. 2012). In Finland, the discussion has focused especially on the As-genotype and its virulence, which in recently reported cases seems to be lowered (Jussila et al. 2011a, Viljamaa-Dirks et al. 2011). Similar observations have also been made in Turkey (Kokko et al. 2012, Svoboda et al. 2012), which is within the current distribution range of the As-genotype (Royo et al. 2004).

In previous studies, the resistance of different crayfish species (Unestam 1969a, 1972, 1975) or the effects of different temperatures, water mineral content and zoospore densities to the progress of the disease (Alderman et al. 1987) have been the main focus. However, possible differences in the virulence of crayfish plague isolates on noble crayfish Astacus astacus populations have not been fully evaluated. So far, most Aphanomyces astaci isolates have not been tested for virulence in controlled experiments. Also, experiments testing between-population differences in resistance against crayfish plague isolates are lacking. The aim of this study was to compare different A. astaci isolates and noble crayfish populations in controlled laboratory conditions to test (1) whether there are differences either in the virulence of different isolates of $A$. astaci, especially within the As-genotype, and (2) whether there are differences among noble crayfish populations, especially among those with different crayfish plague history, in their resistance against $A$. astaci infection. The study consisted of 3 separate infection experiments.

\section{MATERIALS AND METHODS}

\section{Crayfish populations}

Three Finnish noble crayfish populations (a farmed population from the crayfish farm ESeppä and 2 natural populations from Lakes Viitajärvi and Rytky) were taken to the University of Eastern Finland
(UEF) Fish Research Unit in Kuopio and maintained in tanks beginning in August 2010. The farmed population of crayfish from ESeppä was obtained from Haapajärvi $\left(64^{\circ} 1^{\prime} 13.089^{\prime \prime} \mathrm{N}, 25^{\circ} 33^{\prime} 11.973^{\prime \prime} \mathrm{E}\right)$, the Lake Viitajärvi population originated from Tervo $\left(63^{\circ} 1^{\prime} 51.02^{\prime \prime} \mathrm{N}, 26^{\circ} 47^{\prime} 58.635^{\prime \prime} \mathrm{E}\right)$, and the Lake Rytky population originated from Kuopio (62 $51^{\circ} 25.814^{\prime \prime} \mathrm{N}$, $27^{\circ} 25^{\prime} 6.849^{\prime \prime}$ E). Crayfish total length was $\sim 8$ to $9 \mathrm{~cm}$.

During holding, different populations and sexes were kept in separate $200 \mathrm{l}$ tanks ( $2 \mathrm{~m}^{2}$ each). The crayfish were provided with individual hiding places ( $\varnothing 0 \mathrm{~mm}$ ) made of black plastic pipes. Tanks contained filtered Lake Kallavesi water $(5 \mu \mathrm{m}$ filtration with Pleatflow II absolute filter, Dominic Hunter Technologies). The water temperature during holding was similar to ambient water temperature in Lake Kallavesi. Closed water circulation inside each tank was generated with aquarium pumps (Compact 600, Eheim GmbH). Crayfish were fed ad libitum with peas, carrots, green beans, or frozen fish, and the tanks were cleaned and fresh water added once a week.

Crayfish were transferred from the holding tanks to the infection laboratory $1 \mathrm{wk}$ prior to the experiment for acclimation. The experiments (Expts I, II, and III, see below) were initiated after 1, 5, and 7 mo of holding the crayfish in the UEF Fish Research Unit.

\section{Aphanomyces astaci isolates}

Four Finnish isolates of the crayfish plague agent Aphanomyces astaci were used in the experiments. Highly virulent UEF8866-2 (Jussila et al. 2011b) isolated in 2003 from the signal crayfish Pacifastacus leniusculus of Lake Puujärvi in Karjalohja $\left(25^{\circ} 33^{\prime}\right.$ $11.973^{\prime \prime} \mathrm{N}, 23^{\circ} 42^{\prime} 1.111^{\prime \prime}$ E) represented the PsI-genotype, hereafter PsI-Puujärvi. Three isolates of the Asgenotype isolated from the noble crayfish were used: UEFT2B (As-Kemijoki) was isolated in 2007 from Taivalkoski-region crayfish of the River Kemijoki epidemic (66 ${ }^{\circ} 4^{\prime} 44.892^{\prime \prime} \mathrm{N}, 24^{\circ} 47^{\prime} 52.718^{\prime \prime}$ E), Evira6462/ 06 (As-Kivesjärvi) isolated in 2006 from crayfish of the Lake Kivesjärvi epidemic $\left(64^{\circ} 26^{\prime} 38.041^{\prime \prime} \mathrm{N}, 27^{\circ} 25^{\prime}\right.$ 16.826" E), and Evira8372/09 (As-Pajakkajoki) isolated in 2009 from crayfish of the River Pajakkajoki epidemic $\left(64^{\circ} 26^{\prime} 38.041^{\prime \prime} \mathrm{N}, 27^{\circ} 25^{\prime} 16.826^{\prime \prime} \mathrm{E}\right)$. The latter 2 isolates were provided for this study by the Finnish Food and Safety Authority Evira, Kuopio, Finland. Isolates were cultured and maintained in PG1agar (Unestam 1965). Isolates were previously characterized based on ITS- (Makkonen et al. 2011) and chitinase-sequencing (Makkonen et al. 2012). 


\section{Aphanomyces astaci zoospore production}

For zoospore production, a $4 \mathrm{~mm}^{2}$ piece containing Aphanomyces astaci hyphae was cut from PG1 agar and inserted in $45 \mathrm{ml}$ of liquid PG1 medium (Unestam 1965). The cultures were incubated at room temperature, $20 \pm 2^{\circ} \mathrm{C}$ for $1 \mathrm{wk}$, after which the hyphae were cut with a sterile scalpel into small fragments. The resulting hyphae were then transferred into $200 \mathrm{ml}$ of fresh liquid PG1 medium and grown for $3 \mathrm{~d}$ at room temperature. Twelve replicate cultures were made of each $A$. astaci isolate to obtain necessary zoospore numbers for the infections.

Zoospore production was induced by the removal of PG1 medium and washing the hyphae with autoclaved lake water (Cerenius et al. 1988). Aphanomyces astaci was washed in $600 \mathrm{ml}$ of lake water in a vertical shaker at room temperature for $1 \mathrm{~h}$. The wash was repeated 4 times with fresh sterile lake water, and the hyphae were then left in the fourth lake water batch in a vertical shaker for $20 \mathrm{~h}$ at $18^{\circ} \mathrm{C}$. The zoospore density was counted using a Bürker chamber from the pooled zoospore suspension.

\section{Infection experiments: environment and experimental design}

The study was conducted in 3 separate parts (Expts I, II, and III; Table 1 and the following text). The RapuLatorio infection system (Jussila et al. 2011b) and filtered Lake Kallavesi water were used in all of the infection trials. The experimental system consisted of 10 individual tank systems with 3 small adjacent tanks (each 8 l) connected to a sump tank (30 1). In each small tank, 4 crayfish were held in individual compartments. The system enabled cleaning and water quality monitoring without disturbing the crayfish.

Crayfish were infected by adding zoospores to the small tanks. Prior to zoospore addition, water circulation was stopped, and was kept off for $16 \mathrm{~h}$, so that the encapsulated zoospores would start swimming again. During the infection experiments, the crayfish were monitored daily, and notes were made on behavior (restlessness, carapace scratching, loss of orientation, and finally indications of mortality) and feeding (especially cessation of feeding). Moribund individuals were removed immediately and frozen $\left(-20^{\circ} \mathrm{C}\right)$ for further molecular analyses, and surviving crayfish were collected for molecular analyses. The temperature was adjusted to $19^{\circ} \mathrm{C}$ to avoid the temperature affecting the mortality rates
(Alderman et al. 1987, CEFAS 2000). The length of the trials was chosen to represent at least the length of the fastest growing season for crayfish during the Finnish summer.

In Expt I, 36 crayfish from Lake Viitajärvi and 36 from Lake Rytky were used. Both populations were randomly divided into 3 groups, each containing 12 crayfish with an equal sex ratio. One group was used as a control; one was infected with PsI-Puujärvi and one with As-Kemijoki. For the infection in this experiment, Aphanomyces astaci zoospore density was adjusted to 2250 zoospores $\mathrm{ml}^{-1}$, calculated for the 81 infection system water volume.

In Expt II, 60 crayfish from each of Lake Viitajärvi and farmed ESeppä were used, with an equal number of sexes. Infections were made with the Aphanomyces astaci isolates As-Kivesjärvi and As-Pajakkajoki. In both crayfish populations, 1 group $(\mathrm{n}=12)$ was used as a control group, and 2 groups ( $n=24$ in each group) were used for infections with As-Kemijoki and As-Pajakkajoki. Each group had an equal number of males and females. Zoospore densities were adjusted equally, and the exposure was performed with 2440 zoospores $\mathrm{ml}^{-1}$.

In Expt III, crayfish from Lake Viitajärvi ( $\mathrm{n}=42$ ) and Lake Rytky $(\mathrm{n}=58)$ were used. Infections were made with the Aphanomyces astaci isolates AsKivesjärvi and As-Kemijoki. The Lake Rytky population consisted of 35 females and 23 males and the Lake Viitajärvi population of 34 females and 8 males. In the Lake Rytky population, 1 group ( $\mathrm{n}=6$ females + 6 males) was used as a control group, and 2 groups ( $\mathrm{n}=12$ females +10 males; and $\mathrm{n}=17$ females +7 males) were used for infections with As-Kivesjärvi and As-Kemijoki, respectively. In the Lake Viitajärvi population, 1 group was used as a control $(\mathrm{n}=6$ females), the second group infected with As-Kemijoki ( $\mathrm{n}=12$ females), and the third group infected with As-Kivesjärvi ( $\mathrm{n}=16$ females +8 males). Zoospore densities were adjusted equally, to 810 zoospores $\mathrm{ml}^{-1}$.

\section{qPCR of experimental crayfish}

For the qPCR-analyses, all dead control crayfish, all or a subsample of the individuals that survived the infections, and a few individuals that had died during the experiment were selected. Frozen crayfish were thawed at room temperature, and the surface of the cuticle was cleaned with a cotton tip dipped in $70 \%$ ethanol and then with Milli-Q water. Tissue samples were taken from uropod tips (2 uropod tips and 1 tel- 
son tip), and DNA was extracted using an EZNA Insect DNA Isolation Kit (Omega Bio-Tek). The presence of Aphanomyces astaci DNA was analyzed in 2 replicates of $10 \times$ diluted samples with TaqMan ${ }^{\circledR}$ MGB qPCR (Vrålstad et al. 2009). A Kaplan-Meier survival test on SPSS v. 17 was used to evaluate differences in mortality among experimental groups, with a Mantel-Cox test applied for the individual cases.

\section{RESULTS}

\section{Experiment I}

In Expt I, we observed increased mortality as a result of the PsI-Puujärvi (Mantel-Cox, $\chi^{2}=71.418$, df $=1, \mathrm{p}<0.0001)$ and As-Kemijoki (Mantel-Cox, $\chi^{2}=$ 28.734, $\mathrm{df}=1, \mathrm{p}<0.0001$ ) Aphanomyces astaci infections, except for As-Kemijoki-infected Lake Viitajärvi crayfish, which did not show increased mortality. The PsI-Puujärvi crayfish plague caused 100\% mortality after 5 to $6 \mathrm{~d}$ from the initial infection among crayfish from Lakes Viitajärvi and Rytky (Fig. 1), and the mortality rate did not differ between the populations (Mantel-Cox, $\chi^{2}=2.261$, df $=1, \mathrm{p}>$ 0.05). The As-Kemijoki crayfish plague did not cause any mortality, or even symptoms, among the Lake Viitajärvi crayfish population within $42 \mathrm{~d}$, but induced a significantly higher $84 \%(n=10)$ mortality during $42 \mathrm{~d}$ among noble crayfish from the Lake Rytky population (MantelCox $\left., \chi^{2}=16.954, \mathrm{df}=1, \mathrm{p}<0.0001\right)$. A single death ( $8 \%$ mortality) was observed in the control group of Lake Rytky crayfish. A statistically significant difference in mortality was observed between the PsI-Puujärvi and As-Kemijoki infections (Mantel-Cox, $\chi^{2}=$ 71.418, df $=1, \mathrm{p}<0.0001$ ).

\section{Experiment II}

We observed increased mortality as a result of the As-genotype Aphanomyces astaci infection in Expt II in both farmed ESeppä and Lake Viitajärvi populations (Mantel-Cox, $\chi^{2}>71$, df $=2, \mathrm{p}<0.0001$ ). In the Lake Viitajärvi population infected with As-Kivesjärvi, mortality occurred 5 d after infection, and $100 \%$ mortality was achieved within the next $9 \mathrm{~d}$ (14th day since infection). The highest mortality rate was seen during the 8 to $12 \mathrm{~d}$ after the infection (Fig. 2). In the farmed ESeppä population, mortalities started on the sixth day following infection, and the last crayfish in this group (100\% mortality) died on the 25th day following infection. The highest mortality rate was seen between 11 and $15 \mathrm{~d}$ after infection.

With the As-Pajakkajoki isolate, mortality in the Lake Viitajärvi population started after the fifth day since infection, and the mortality rate was significantly slower than in the crayfish group infected with As-Kivesjärvi (Mantel-Cox, $\chi^{2}=24.857$, df $=1, \mathrm{p}<$ 0.0001). Mortality occurred between 11 and $25 \mathrm{~d}$ following infection, after which $100 \%$ mortality was reached. In the farmed ESeppä crayfish, mortality started on the ninth day after infection, and then mortalities were evenly distributed until $100 \%$ mortality was reached $25 \mathrm{~d}$ after infection. In the farmed ESeppä and Lake Viitajärvi population, a mortality of $33 \%(\mathrm{n}=4)$ and $8 \%(\mathrm{n}=1)$ in the controls, respectively, was observed. In farmed ESeppä controls, the mortalities occurred early in the experiment, concurrently with initial mortalities in the PsI-Puujärviinfected group (Fig. 2).

\section{Experiment III}

We observed an increased mortality as a result of the As-Kivesjärvi Aphanomyces astaci infection in

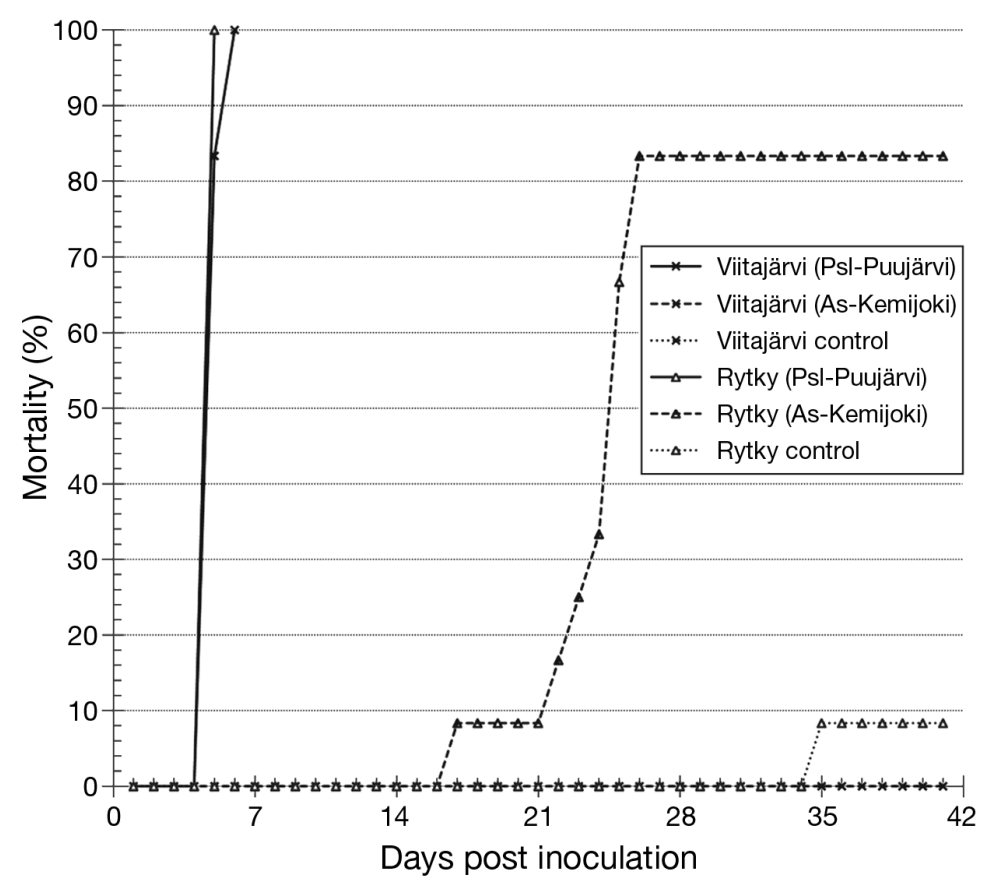

Fig. 1. Astacus astacus infected with Aphanomyces astaci. Cumulative crayfish mortality during infection Expt I 
Expt III (Mantel-Cox, $\chi^{2}>29$, df $=1, \mathrm{p}<$ 0.0001) in both Lake Rytky and Lake Viitajärvi crayfish, while those infected with AsKemijoki did not show increased mortality. In both populations tested, infections with As-Kivesjärvi $A$. astaci caused an acute infection, with mortalities starting at $11 \mathrm{~d}$ after infection, and $100 \%$ mortality $(n=24)$ in both tested populations was reached by $19 \mathrm{~d}$ following infection (Fig. 3). Infections with As-Kemijoki caused a $17 \%(n=2)$ mortality among the Lake Viitajärvi crayfish population and a single death (4.5\%) among the Lake Rytky crayfish during the $50 \mathrm{~d}$ followup period, with no statistical difference to controls (Mantel-Cox, $\chi^{2}>2, \mathrm{df}=1, \mathrm{p}>0.05$ ). In the Lake Rytky control group, $8.5 \%$ mortality $(\mathrm{n}=1)$ occurred during the experiment. A statistically significant difference in mortality rate was found between the groups infected with $A$. astaci isolates As-Kivesjärvi and As-Kemijoki (MantelCox $, \chi^{2}=96.796, d f=1, p<0.0001$ ).

\section{qPCR-analyses}

In Expt I, surviving crayfish from both populations, Lake Rytky $(\mathrm{n}=2)$ and Lake Viitajärvi $(\mathrm{n}=5)$, infected with As-Kemijoki tested positive to Aphanomyces astaci at the agent level of A2, which corresponds to Ct-values between 39 and 34.7 (Vrålstad et al. 2009). The Lake Rytky control that died during the experiment $(\mathrm{n}=1)$ tested negative to $A$. astaci infection.

In Expt II, infected surviving crayfish from farmed ESeppä ( $\mathrm{n}=8)$ and Lake Viitajärvi $(\mathrm{n}=8)$ populations tested positive to Aphanomyces astaci at agent levels of $\mathrm{A} 4$ (Ct 30.0-26.2) to A5 (Ct 26.2-22.6) and A3 (Ct 34.7-30.0) to A4, respectively. The farmed ESeppä controls that died during the experiment $(\mathrm{n}=4)$, tested negative for $A$. astaci, while the only dead Lake Viitajärvi control $(\mathrm{n}=1)$ tested positive with a low agent level (A2; Ct 39.0-34.7), which may indicate a low-level background infection.

In Expt III, As-Kivesjärvi-infected crayfish from the Lake Viitajärvi population $(\mathrm{n}=6)$ tested positive at an agent level of A4, while in the Lake Rytky population $(n=5)$, the agent level was lower (A3). As-Kemi-

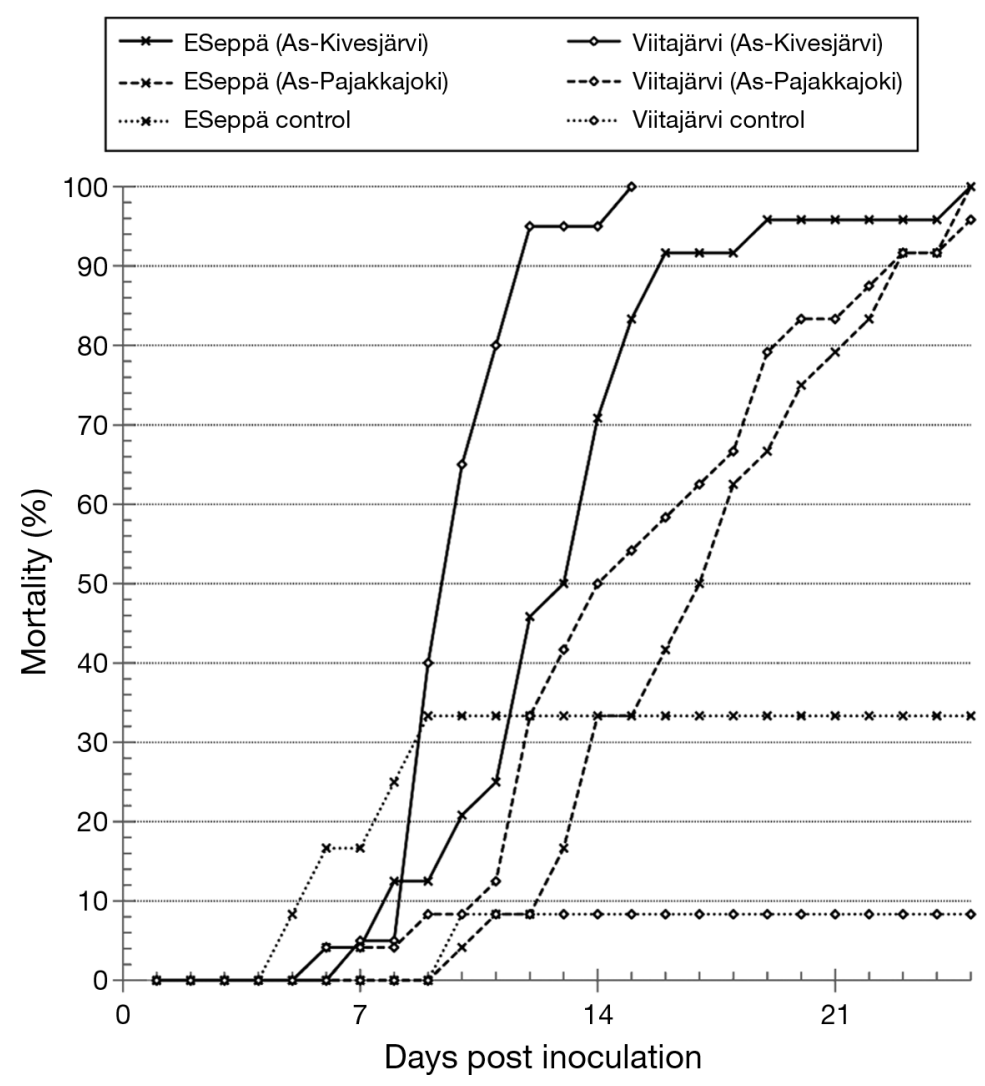

Fig. 2. Astacus astacus infected with Aphanomyces astaci. Cumulative crayfish mortality during infection Expt II

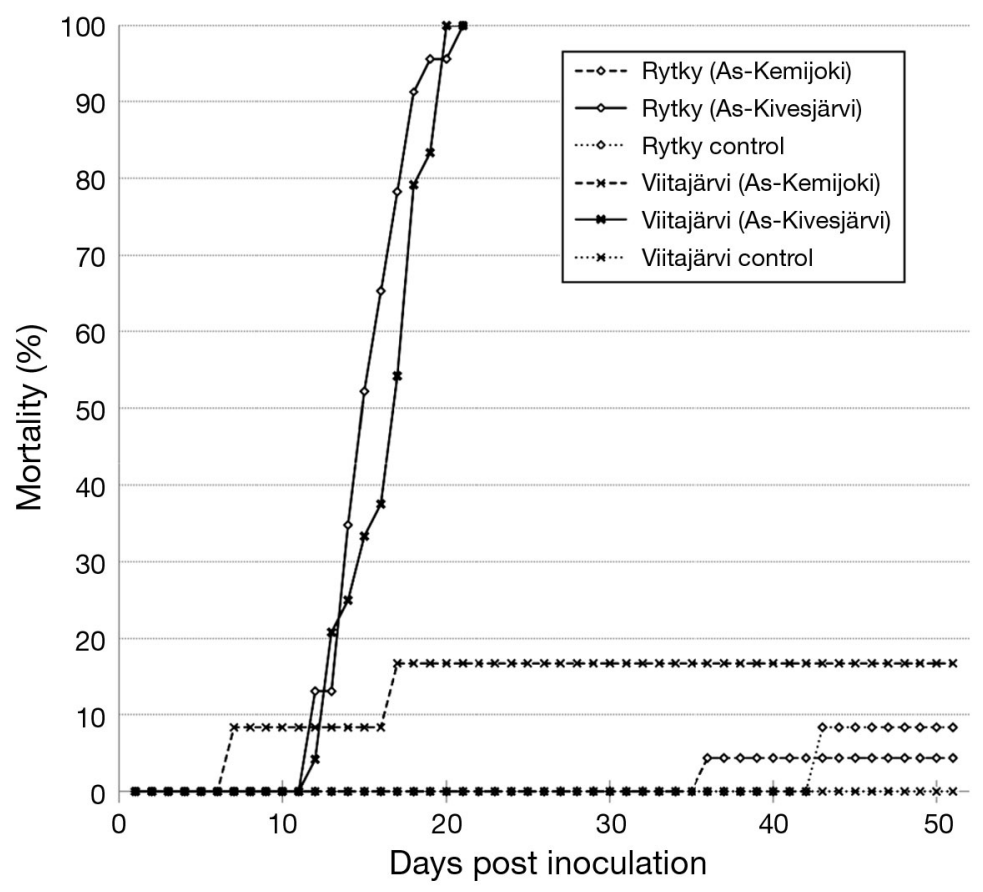

Fig. 3. Astacus astacus infected with Aphanomyces astaci. Cumulative crayfish mortality during infection Expt III 
joki infected Lake Rytky crayfish $(\mathrm{n}=5)$ that survived tested negative, while in the Lake Viitajärvi population the agent infection level of surviving crayfish ( $\mathrm{n}=4$ ) was just below the detection limit (A1). Crayfish infected with As-Kemijoki from the Lake Viitajärvi population that died during the experiment $(\mathrm{n}=2)$ showed low but detectable agent levels in the studied tissues (A2).

\section{DISCUSSION}

Our data indicate for the first time that considerable variation exists in the virulence among Aphanomyces astaci isolates within the As-genotype. Further, the PsI-genotype isolate from Lake Puujärvi was more virulent than any of the tested As-genotype isolates. Interestingly, we also found detectable variation in resistance among some of the tested noble crayfish populations, although we could not confirm this variation to be genetic at this stage.

In Expt I, PsI-Puujärvi killed all infected crayfish within $7 \mathrm{~d}$. As a side result, we observed that the crayfish infected with PsI-Puujärvi became heavily symptomatic $1 \mathrm{~d}$ prior to their death. Symptomatic crayfish showed agitation by intense scratching of the carapace. Among the crayfish infected with Asgenotype Aphanomyces astaci, the symptom preceding death was a paralysis-like state, i.e. the immobilization of the crayfish, which occurred some 2 to $4 \mathrm{~d}$ prior to death. In all isolates tested, symptoms were always followed by death, while the surviving crayfish showed no symptoms.

Since the number of zoospores used in the infection trials in different experiments varied, as did the physiological stage of the crayfish, our results might not be directly comparable among the 3 experiments. However, among the As-genotype isolates that were tested, As-Kivesjärvi seemed the most virulent isolate. As-Pajakkajoki can be evaluated as an intermediate-virulence isolate, while As-Kemijoki can be judged as a relatively low-virulence isolate.

In Expt I, As-Kemijoki killed $84 \%$ of the Lake Rytky population crayfish, but no increase in mortality was observed among the Lake Viitajärvi population. In Expt III, only $4.5 \%$ mortality among the As-Kemijoki-infected Lake Rytky population crayfish was observed, and the mortality among the Lake Viitajärvi crayfish was slightly higher. In Expt III, the mortality rate of the As-Kemijoki-infected crayfish was low in both tested populations and similar to the mortality rate in the non-infected control groups.
There may be several reasons for the low mortality rates observed in the As-Kemijoki-infected crayfish. One of the reasons could be the zoospore density. In Expt I, the zoospore density was roughly 3 times higher than in Expt III (2250 and 810 zoospores $\mathrm{ml}^{-1}$, respectively). This may have caused the low mortality in both tested populations during Expt III. An effect of zoospore density on mortality rate was observed in a previous study by Alderman et al. (1987), although in that study, narrow-clawed crayfish Astacus leptodactylus were used in infection experiments, and the zoospore densities were 100x lower than in our study. By lowering the zoospore densities from the maximum amounts used in our experiments, probably even more variation in both crayfish plague virulence and crayfish resistance would have been observed.

Previously, the isolate J1 from Lake Ämmern (Sweden) was reported to turn non-virulent after years of cultivation in laboratory conditions (Unestam 1969b). In that case, the isolate was reported to lose the motility of the zoospores first, and then, approximately 1 yr later, it lost its virulence (Unestam 1969b). With the As-Kemijoki isolate, we did not observe a loss of zoospore motility, and substantial amounts of motile zoospores were produced for the initial infection during our experiments. Quantitative PCR (Vrålstad et al. 2009) results showed that low amounts of Aphanomyces astaci DNA were also present in the individuals who survived until the end of Expts I and III. In Expt I, infection levels of the surviving crayfish stayed at agent level A2, meaning weak infection or carrier status, in both populations. In Expt III, the surviving crayfish from Lake Rytky had agent levels below the detection limit of qPCR (A0, no infection), and agent levels of Lake Viitajärvi crayfish were just above the detection limit (A1, meaning $<1$ spore per sample). These results most likely indicate that there are either problems in the attachment and germination of As-Kemijoki zoospores, or the crayfish are able to resist the infection of such a weak A. astaci strain. Therefore, the infection and the disease development are stopped at a very early stage or are completely inhibited. However, the mechanisms behind this observation are as yet unknown, and will hopefully be clarified in further studies.

In Expt II, a single death in the control group of Lake Viitajärvi crayfish was observed. In the qPCRanalyses, which were made twice, this sample showed low level (A2) infection with Aphanomyces astaci. This single positive observation may reflect low-level carrier status (Jussila et al. 2011a), or indi- 
cate that sporadic spores may have been transferred to the control group during the experiment. All other tested dead control crayfish remained negative in the qPCR-analyses.

Isolates As-Kivesjärvi and As-Pajakkajoki both caused $100 \%$ mortality in Expt II. The mortality rate of As-Kivesjärvi was faster than that of As-Pajakkajoki. Both of these As-genotype isolates can be considered virulent, as $100 \%$ mortality was achieved within $21 \mathrm{~d}$ after initial infection. Nevertheless, the mortality rate was considerably slower in comparison with the PsI-Puujärvi isolate in Expt I, both experiments having a comparable zoospore density during initial infection.

A significant difference in the resistance towards Aphanomyces astaci infection was observed in Expt I between As-Kemijoki-infected Lake Rytky and Lake Viitajärvi crayfish. It seems that noble crayfish can delay the crayfish plague infection of the As-genotype isolate under certain conditions. Infection status may be dependent on the physical condition of an individual crayfish or a whole population. Under natural conditions, the population density, water temperature, and some other unknown factors with low A. astaci zoospore density may induce delayed or latent infection (Jussila et al. 2011b, Viljamaa-Dirks et al. 2011).

Based on these 3 experiments, we conclude that considerable variation in virulence exists among the As-genotype isolates of Aphanomyces astaci, and the signal crayfish Pacifastacus leniusculus-related PsIPuujärvi expresses higher virulence and induces different symptoms than the As-genotype. We also observed some signs of increased resistance towards A. astaci infection among different crayfish populations held under common conditions for a considerable time, and it seems that certain noble crayfish populations may be able to resist certain As-genotype infections at least for a limited time period, under experimental conditions. These results indicate that genetic adaptation within the As-genotype could have occurred during its $120 \mathrm{yr}$ history in Finland. Finally, it is still very evident that close attention must be paid to the origin and disease status of the noble crayfish populations used as stocking material to avoid the further spread of this disastrous disease.

Acknowledgements. This study was funded by the Ministry of Forestry and Agriculture and UEF Innovative Research Initiative funding. We thank $\mathrm{H}$. Kukkonen for assistance during the experiments. Two Aphanomyces astaci isolates were kindly provided by S. Viljamaa-Dirks, Finnish Food Safety Authority (Kuopio).

\section{LITERATURE CITED}

Alderman DJ (1996) Geographical spread of bacterial and fungal diseases of crustaceans. Rev Sci Tech 15:603-632

> Alderman DJ, Polglase JL, Frayling M (1987) Aphanomyces astaci pathogenicity under laboratory and field conditions. J Fish Dis 10:385-393

CEFAS (Centre for Environment, Fisheries and Aquaculture Science) (2000) Summary final report: effects of exposure to high and low temperatures on the survival of the crayfish plague fungus $A$. astaci in vitro and in vivo. Australian Quarantine and Inspection Service, Canberra

Cerenius L, Söderhäll K, Persson M, Ajaxon R (1988) The crayfish plague fungus Aphanomyces astaci-diagnosis, isolation and pathobiology. Freshw Crayfish 7:131-144

Cornalia E (1860) Sulla malattia dei gamberi. Atti Soc Ital Sci Nat 2:334-336

> Diéguez-Uribeondo J, Huang T, Cerenius L (1995) Physiological adaptation of an Aphanomyces astaci strain isolated from the freshwater crayfish Procambarus clarkii. Mycol Res 99:574-578

Hochwimmer G, Tober R, Bibars-Reiter R, Licek E, Steinborn R (2009) Identification of two GH18 chitinase family genes and their use as targets for detection of the crayfish-plague oomycete Aphanomyces astaci. BMC Microbiol 9:184-201

> Huang T, Cerenius L, Söderhäll K (1994) Analysis of genetic diversity in the crayfish plague fungus, Aphanomyces astaci, by random amplification of polymorphic DNA. Aquaculture 126:1-9

Jussila J, Makkonen J, Vainikka A, Kortet R, Kokko H (2011a) Latent crayfish plague (Aphanomyces astaci) infection in a robust wild noble crayfish (Astacus astacus) population. Aquaculture 321:17-20

Jussila J, Makkonen J, Kokko H (2011b) Peracetic acid (PAA) treatment is an effective disinfectant against crayfish plague (Aphanomyces astaci) spores in aquaculture. Aquaculture 320:37-42

Kokko H, Koistinen L, Harlio lu MM, Makkonen J, Aydin H, Jussila J (2012) Recovering Turkish narrow clawed crayfish (Astacus leptodactylus) populations carry Aphanomyces astaci. Knowl Manag Aquat Ecosyst 404:12

> Kozubiková E, Viljamaa-Dirks S, Heinikainen S, Petrusek A (2011) Spiny-cheek crayfish Orconectes limosus carry a novel genotype of the crayfish plague pathogen Aphanomyces astaci. J Invertebr Pathol 108:214-216

> Makkonen J, Jussila J, Henttonen P, Kokko H (2011) Genetic variation in the ribosomal internal transcribed spacers of Aphanomyces astaci Schikora from Finland. Aquaculture 311:48-53

Makkonen J, Jussila J, Kokko H (2012) The diversity of the pathogenic oomycete (Aphanomyces astaci) chitinase genes within the genotypes indicate adaptation to its hosts. Fungal Genet Biol 49:635-642

Oidtmann B, Geiger S, Steinbauer P, Culas A, Hoffmann RW (2006) Detection of Aphanomyces astaci in North American crayfish by polymerase chain reaction. Dis Aquat Org 72:53-64

Pârvulescu L, Schrimpf A, Kozubíková E, Cabnillas Resino S, Vrålstad T, Petrusek A, Schulz R (2012) Invasive crayfish and crayfish plague on the move: first detection of the plague agent Aphanomyces astaci in the Romanian Danube. Dis Aquat Org 98:85-94

Royo F, Andersson G, Bangyeekhun E, Muzquiz JL, Söderhäll K, Cerenius L (2004) Physiological and genetic char- 
acterisation of some new Aphanomyces strains isolated from freshwater crayfish. Vet Microbiol 104:103-112

Söderhäll K, Cerenius L (1999) The crayfish plague fungus: history and recent advances. Freshw Crayfish 12:11-35

Souty-Grosset C, Holdich DM, Noël PY, Reynolds JD, Haffner P (eds) (2006) Atlas of crayfish in Europe. Muséum national d'Histoire naturelle, Paris

Svoboda J, Kozubíková E, Kozák P, Kouba A and others (2012) PCR detection of the crayfish plague pathogen in narrow-clawed crayfish inhabiting Lake Eğirdir in Turkey. Dis Aquat Org 98:255-259

Unestam T (1965) Studies on the crayfish plague fungus Aphanomyces astaci I. Some factors affecting growth in vitro. Physiol Plant 18:483-505

Unestam T (1969a) Resistance to the crayfish plague in some American, Japanese and European crayfishes. Rep Inst Freshw Res Drottningholm 49:202-209

Unestam T (1969b) On the adaptation of Aphanomyces astaci as a parasite. Physiol Plant 22:221-235

Unestam T (1972) On the host range and origin of the crayfish plague fungus. Rep Inst Freshw Res Drottningholm 52:192-198

Editorial responsibility: Grant Stentiford, Weymouth, UK
Unestam T (1975) Defense reactions in and susceptibility of Australian and New Guinean freshwater crayfish to European-crayfish-plague fungus. Aust J Exp Biol Med Sci 53:349-359

Unestam T, Weiss DW (1970) The host-parasite relationship between freshwater crayfish and the crayfish disease fungus Aphanomyces astaci: responses to infection by a susceptible and resistant species. J Gen Microbiol 60:77-90

Vennerström P, Söderhäll K, Cerenius L (1998) The origin of two crayfish plague (Aphanomyces astaci) epizootics in Finland on noble crayfish, Astacus astacus. Ann Zool Fenn 35:43-46

Viljamaa-Dirks S, Heinikainen S, Nieminen N, Vennerström P, Pelkonen S (2011) Persistent infection by crayfish plague Aphanomyces astaci in a noble crayfish population-a case report. Bull Eur Assoc Fish Pathol 31: 182-188

Vrålstad T, Knutsen AK, Tengs T, Holst-Jensen A (2009) A quantitative TaqMan ${ }^{\circledR}$ MGB real-time polymerase chain reaction based assay for detection of the causative agent of crayfish plague Aphanomyces astaci. Vet Microbiol $137: 146-155$

Submitted: July 2, 2012; Accepted: October 28, 2012

Proofs received from author(s): December 19, 2012 